\title{
Performance evaluation of power chaff cutter
}

\author{
U.S. KANKAL, D.S. KARALE, V. P. KHAMBALKAR AND S.H. THAKARE
}

\section{ABSTRACT}

The ever increasing energy demand, unemployment in developing countries like India, Increased awareness of people towards the health are some of the driving forces for the development of powered machines. The experimentation has been carried out on a fodder cutter energized by electrical power. Fodder-cutter machines are used every day by farmers and their families in India for preparation of fodder for the livestock they own. This paper discus about the procedure of the testing of fodder cutter machine.

KEY WORDS : Chaff cutter, Performance, Load condition, Power consumption, Fodder

How to cite this Article : Kankal, U.S., Karale, D.S., Khambalkar, V.P. and Thakare, S.H. (2016). Performance evaluation of power chaff cutter. Engg. \& Tech. in India, 7 (1) : 18-25. 